\title{
PRISM3/GISS Topographic Reconstruction
}

Data Series 419 


\section{PRISM3/GISS Topographic Reconstruction}

By Linda E. Sohl, Mark A. Chandler, Robert B. Schmunk, Ken Mankoff, Jeffrey A. Jonas, Kevin M. Foley, and Harry J. Dowsett

Prepared in cooperation with NASA Goddard Institute for Space Studies, and the Center for Climate Systems Research at Columbia University

Data Series 419 


\title{
U.S. Department of the Interior \\ KEN SALAZAR, Secretary
}

\author{
U.S. Geological Survey \\ Suzette M. Kimball, Acting Director
}

U.S. Geological Survey, Reston, Virginia: 2009

For more information on the USGS - the Federal source for science about the Earth, its natural and living resources, natural hazards, and the environment, visit http://www.usgs.gov or call 1-888-ASK-USGS

For an overview of USGS information products, including maps, imagery, and publications, visit http://www.usgs.gov/pubprod

To order this and other USGS information products, visit http://store.usgs.gov

Any use of trade, product, or firm names is for descriptive purposes only and does not imply endorsement by the U.S. Government.

Although this report is in the public domain, permission must be secured from the individual copyright owners to reproduce any copyrighted materials contained within this report.

Suggested citation:

Sohl, L.E., Chandler, M.A., Schmunk, R.B., Mankoff, Ken, Jonas, J.A., Foley, K.M., and Dowsett, H.J., 2009, PRISM3/ GISS topographic reconstruction: U.S. Geological Survey Data Series 419, 6 p. 


\section{Contents}

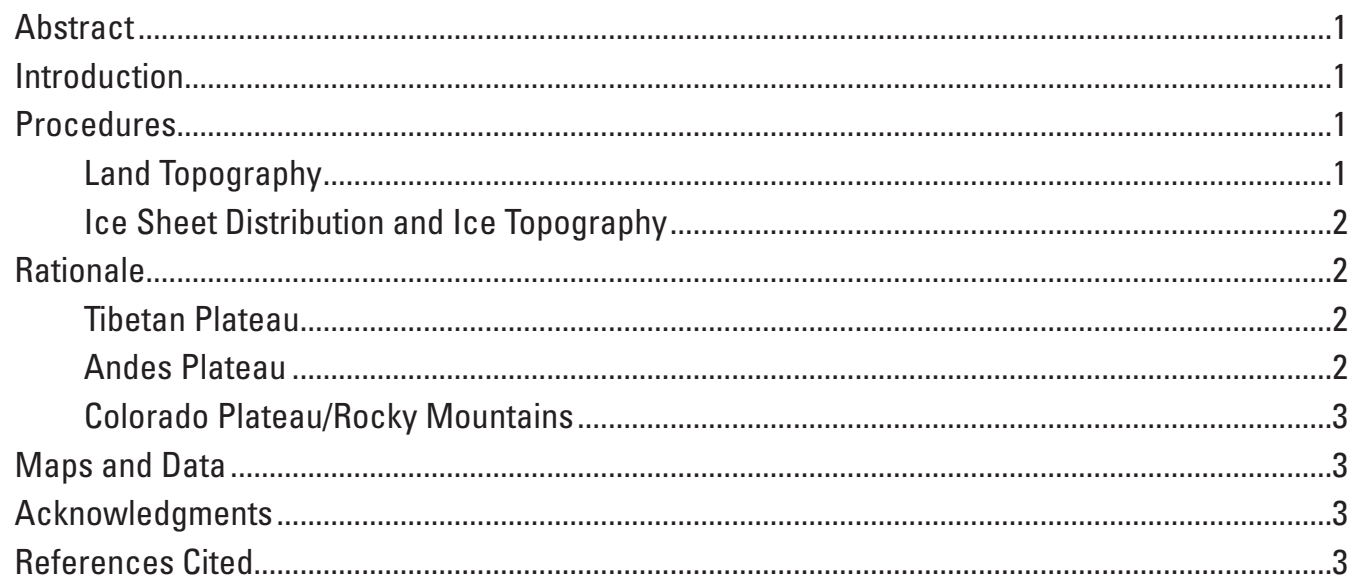

\section{Figures}

1. Reconstructed PRISM3/GISS topography (GISS_P3_topo_v1.0).

2. Anomaly map showing the elevation changes made for the PRISM3/GISS topography with respect to the older PRISM2 topography.

\section{Conversion Factors}

\begin{tabular}{|c|c|c|}
\hline Multiply & By & To obtain \\
\hline \multicolumn{3}{|c|}{ Length } \\
\hline meter (m) & 3.281 & foot (ft) \\
\hline kilometer $(\mathrm{km})$ & 0.6214 & mile (mi) \\
\hline
\end{tabular}

\section{Abbreviations used in this report:}

BAS
BAS ISM
EAIS
GCM
GISS
ISM
NOAA
Ma
PNG
PRISM
RGB
SLR
USGS

approximately

British Antarctic Survey

British Antarctic Survey Ice Sheet Model

East Antarctic Ice Sheet

General Circulation Model

Goddard Institute for Space Studies

Ice Sheet Model

National Oceanic and Atmospheric Administration

Mega-annum

Portable Network Graphics

Pliocene Research, Interpretation and Synoptic Mapping

Red, Green, and Blue

Sea Level Rise

U.S. Geological Survey 



\title{
PRISM3/GISS Topographic Reconstruction
}

\author{
Linda E. Sohl, ${ }^{12}$ Mark A. Chandler, ${ }^{12}$ Robert B. Schmunk, ${ }^{2}$ Ken Mankoff,, ${ }^{12}$ Jeffrey A. Jonas, ${ }^{12}$ Kevin M. Foley, ${ }^{3}$ \\ and Harry J. Dowsett ${ }^{3}$
}

\begin{abstract}
The PRISM3/GISS topographic reconstruction is one of the global data sets incorporated into a new reconstruction for the mid-Piacenzian warm interval of the Pliocene, at about 3.3 to $3.0 \mathrm{Ma}$. The PRISM3/GISS topography-gridded data set is a digitization of a graphical reconstruction, provided at $2^{\circ} \times 2^{\circ}$ resolution and based on updated paleoaltimetry data and a refined land/ocean mask. Mid-Piacenzian topography as shown in this data set is generally quite similar to modern topography, with three notable differences: (1) the coastline as shown is 25 meters higher than modern sea level, reflecting the hypothesized reduction in ice sheet volume; (2) Hudson Bay is filled in to low elevation, in the absence of evidence for submergence at that time; and (3) the West Antarctic ice sheet is absent, permitting open seaways to exist in Ellsworth and Marie Byrd Lands. Two alternate ice sheet configurations with corresponding vegetation schemes are available; one is a minor modification of the PRISM2 ice reconstruction, and one is derived from the British Antarctic Survey Ice Sheet Model (BAS ISM).
\end{abstract}

\section{Introduction}

The PRISM3/GISS topographic reconstruction is a threedimensional global data set representing a best estimation of land and ice sheet relief for use with climate model simulations of the mid-Piacenzian. This time interval ( $\sim 3.3-3.0 \mathrm{Ma}$, or "PRISM interval") has been intensely studied as part of the U.S. Geological Survey Pliocene Research, Interpretation and Synoptic Mapping (PRISM) Project (Dowsett, 2007). This reconstruction was created at the NASA Goddard Institute for Space Studies (GISS) and builds upon the U.S. Geological Survey's previous PRISM2 topography through the incorporation of recent paleoaltimetry data and information derived NY.

Center for Climate Systems Research at Columbia University, New York,

${ }^{2}$ NASA Goddard Institute for Space Studies, New York, NY.

${ }^{3}$ U.S. Geological Survey, Reston, VA. from Markwick's (2007) Pliocene paleogeography. A variant of the PRISM3/GISS topography that incorporates an alternate ice sheet and ice topography reconstruction created by the British Antarctic Survey (Hill and others, 2007) is also available.

\section{Procedures}

\section{Land Topography}

The previous PRISM1/PRISM2 digital topographic reconstruction for the PRISM interval (Dowsett and others, 1994; Thompson and Fleming, 1996), at $2^{\circ} \times 2^{\circ}$ grid resolution, was projected as an equirectangular (equidistant cylindrical) map image, and elevation contours were interpolated for greater ease in further modification. Markwick (2007), as a much more recent reconstruction of Pliocene topography, was generally used as reference for locations where the older PRISM1/PRISM2 map lacked detail at lower elevation ranges (for example, 0-500 meters), and the additional elevation information was drawn in accordingly. Where the PRISM topography supplied additional detail at low elevation, this information was retained and combined with Markwick's data to produce smooth and geologically/geographically consistent elevation changes. Several map reconstructions were then produced, including a version that extrapolates topographic relief to the modern coastlines in order to permit the widest possible use among climate modeling groups with varying ability to modify ocean-continent distribution. In all cases the Hudson Bay region has been raised above sea level, assuming groups can mask that region if they are truly restricted to modern coastlines for experiments.

The maps were digitized using the G.Sampler software program developed at NASA, which analyzes the RGB color values of each pixel, binning the values based on a predefined latitude $\mathrm{x}$ longitude grid overlay. Each RGB combination (pixel) is then assigned a height above sea level, and a weighted average for each grid cell is generated. It should be noted that the northernmost and southernmost rows (first and last row of each array) should be averaged for input into general circulation models (GCMs) that use a single pole-centered cell over the North and South poles. 


\section{Ice Sheet Distribution and Ice Topography}

As with the PRISM2 reconstruction, the topography of ice sheets in Greenland and Antarctica is included with land topography. Two ice sheet distributions are provided: one is a minor modification of the original PRISM2 ice, here called PRISM2', and the other was produced by the British Antarctic Survey Ice Sheet Model (BAS ISM) (see below). Areas of ice sheet distribution are distinguishable in the associated vegetation reconstructions, where ice is assigned as a vegetation type (for example, Salzmann and others, 2008).

PRISM2': This distribution is very similar to the older PRISM2 ice, with minor changes introduced in order to tie ice sheet distribution in Greenland more closely with the topographic reconstruction, as well as to produce a more "natural" outline for Antarctic ice. The size and shape of the Greenland ice sheet are reduced approximately 50 percent from its modern extent (Dowsett and others, 1994; Thompson and Fleming, 1996) in order to supply approximately $4 \mathrm{~m}$ of the required 25-m sea level rise. In Antarctica, the entire West Antarctic ice sheet has been removed to yield another $6 \mathrm{~m}$ of sea level rise. An independent ice sheet model (Michael Prentice, University of New Hampshire, personal commun., 1999, cited in Dowsett and others, 1999) was used to produce a smaller, more realistic East Antarctic ice sheet distribution that accommodated the remaining $15 \mathrm{~m}$ of sea level rise needed for the PRISM interval.

BAS ISM: This ice sheet distribution was created by the British Antarctic Survey Ice Sheet Model, a dynamic ice sheet model run asynchronously with the Hadley Centre's HadAM3 GCM (Hill and others, 2007). A "standard mid-Pliocene climate" experiment was run with the HadAM3, and the output of that run downscaled to a $50-\mathrm{km} \times 50-\mathrm{km}$ grid for use in an array of sensitivity experiments conducted with the ISM. The East Antarctic Ice Sheet (EAIS) in the BAS reconstruction presented here represents the smallest of those ice reconstructions (Hill and others, 2007). In terms of area, the BAS ISM reconstruction is not significantly different from the PRISM2', although the BAS ISM did yield slightly higher elevations across a wider area of the EAIS and portions of the Greenland ice sheet.

\section{Rationale}

As with the PRISM2 reconstruction, Pliocene sea levels are assumed to have been $25 \mathrm{~m}$ higher than present day (Dowsett and others, 1999). To create a coastline reflecting this change, we applied an ocean mask derived from ETOPO5 data (National Oceanic and Atmospheric Administration, 1988) over the modern continental outline, with some adjustments (fig. 1). In a departure from the PRISM2 land/ocean mask, Hudson Bay was filled in at low elevation, assuming that no part of it was yet submerged in Pliocene time. In Antarctica, the West Antarctic ice sheet is absent in this reconstruction, leaving open waterways in locations where the current bedrock elevation is less than $25 \mathrm{~m}$ above modern sea level.

Several terrestrial regions were of particular interest for this reconstruction, since at the time the PRISM1/PRISM2 reconstruction was completed (Dowsett and others, 1994; Thompson and Fleming, 1996) insufficient data were available to provide good constraints on paleoaltimetry. These elevation differences are shown in figure 2 .

\section{Tibetan Plateau}

Original PRISM2 topography: Elevations for the Tibetan Plateau itself were made roughly consistent with the modern day because of uncertainty over the timing of plateau uplift.

Current reconstruction: Elevations were left substantively unchanged, as more recent data suggest that the Tibetan Plateau has long been at or near current elevations. Oxygen isotope data from paleosol carbonates in Tibet imply an elevation of 5,200 $\mathrm{m}$ since the late Miocene ( $10 \mathrm{Ma}$; Garzione, Dettman, and others, 2000; Garzione, Quade, and others, 2000; Rowley and others, 2001) with no recognizable change in height of the High Himalaya since $20 \mathrm{Ma}$ (Rowley and Garzione, 2007). Similar data from the southern Tibetan Plateau (Rowley and Garzione, 2007), in addition to paleoelevation data derived from Late Miocene (15.1 Ma) flora buried in ash (Spicer and others, 2003) suggest an elevation of 4,650 to $5,200 \mathrm{~m}$ by $\sim 15 \mathrm{Ma}$. The central Tibetan Plateau appears to have maintained a fairly consistent elevation in excess of $4,000 \mathrm{~m}$ for the past $\sim 35$ million years (Rowley and Currie, 2006), while isotope data from lake carbonates in the northern portion suggest that this area underwent significant uplift from less than 2,000 $\mathrm{m}$ to its current elevation of $4,700 \mathrm{~m}$ over the past 39 million years (Rowley and Garzione, 2007), although it is likely that the northern plateau had reached something akin to modern elevations by the PRISM interval. Portions of Central Asia beyond the Tibetan Plateau also appear to have achieved a modestly higher elevation than previously thought by this time, and so are shown at elevations some $500 \mathrm{~m}$ higher in the current reconstruction.

\section{Andes Plateau}

Original PRISM2 topography: Thompson and Fleming (1996) reduced the elevation of the western cordillera in northern South America to $\sim 2,000 \mathrm{~m}$, approximately half the modern value, in accordance with available geologic and isotopic studies.

Current reconstruction: Data from multiple isotopic paleoelevation proxies suggest that the central Andes had reached most of their current height (3,600-3,800 m) by 6.8 $\mathrm{Ma}$ (Ghosh and others, 2006; Garzione and others, 2006; Rowley and Garzione, 2007), so only minor adjustments were needed showing an additional $500 \mathrm{~m}$ elevation along parts of the inner edge of the Peru salient/Chile recess. The northern- 
most cordillera was left at elevations a few hundred meters lower than modern, as per Markwick (2007).

\section{Colorado Plateau/Rocky Mountains}

Original PRISM1/PRISM2 topography: Applying data from geologic and isotopic studies available at the time, Thompson and Fleming (1996) decreased the elevation of the western cordillera in North America elevations by half, to a maximum of approximately $1,500 \mathrm{~m}$.

Current reconstruction: A reconstruction of a datum surface used to measure the amount of incision in the Colorado Plateau in the Late Cenozoic (McMillan and others, 2006) suggests that there has not been more than a 750-m increase in elevation since $\sim 35 \mathrm{Ma}$. Modeling of the viscous mantle flow beneath the Colorado Plateau suggests that post-Laramide uplift of this region has been on the order of 1,200 m, much of it occurring within the past 10 million years (Moucha and others, 2008). Markwick (2007) thus gives this region nearmodern topographic relief, which we adopt for this reconstruction; it is roughly 1,500 to 2,000 $\mathrm{m}$ higher than the PRISM2 topography.

\section{Maps and Data}

Multiple versions of the PRISM3/GISS topography are available as both map images and in digitized form. The map images are available in PNG format as supplementary material. Digitized versions of the data are available on the PRISM3 Web site (http://geology.er.usgs.gov/eespteam/prism/) at $2^{\circ} \times 2^{\circ}$ (latitude $\mathrm{x}$ longitude) resolution and are available in two formats: (1) Microsoft ${ }^{\circledR}$ Excel, and (2) as netCDF files. Filenames and descriptions of the data they contain are below.

- GISS_P3_topo_v1.0: Values are given in meters above sea level and this data set incorporates a $25-\mathrm{m}$ sea level rise (SLR) above modern based on ETOPO5 data (National Oceanic and Atmospheric Administration, 1988). The coastline was also modified so that Hudson Bay is above sea level, as are the Great Lakes. The West Antarctic Ice Sheet was removed and shallow seas are present across much of the continent in that region.

- GISS_P2_ice_sheet_v1.0: This data set contains the fractional amount of ice sheet covering each grid cell. Values are given as a fraction of 1.0, with 1.0 representing 100 percent ice sheet cover and 0 percent representing no ice sheet cover.

- BAS_GISS_P3_topo_v1.1: Similar to GISS_P3_topo v1.0, except that the topography for Greenland and Antarctica uses ice sheets simulated by the BAS Ice Sheet Model.
- BAS_GISS P3 ice sheet v1.1: Fractional coverage of the ice sheet distribution simulated by the BAS Ice Sheet Model. Values are given as a fraction of 1.0, with 1.0 representing 100 percent ice sheet cover and 0 percent representing no ice sheet cover.

- GISS_P3_topo_v1.2: Includes the same Pliocene topography as in GISS_P3_topo_v1.0 except that the topographic elevation data are extended to modern coastlines. This is for climate models that cannot easily alter land/sea distributions from modern defaults. As in GISS_P3_topo_v1.0, Hudson Bay and the Great Lakes are above sea level and shallow seas are present across West Antarctica.

- GISS_P3 topo_v1.3: Includes the same Pliocene topography as in GISS_P3 topo_v1.0 except the topographic relief is extended to modern coastlines. As in GISS_P3_topo_v1.0, Hudson Bay and the Great Lakes are above sea level. Unlike v1.2, there are no shallow seas across Antarctica. This is for climate models that cannot easily alter land/sea distributions from modern defaults.

\section{Acknowledgments}

The authors thank P.J. Markwick for sharing his paleotopographic data, and D.B. Rowley for additional information. This work was supported by the USGS Earth Surface Dynamics Program and National Science Foundation Paleoclimate program grant ATM 0323516.

\section{References Cited}

Dowsett, H.J., 2007, The PRISM palaeoclimate reconstruction and Pliocene sea-surface temperature, in Williams, M., Haywood, A.M., Gregory, F.J., and Schmidt, D.N., eds., Deep-time perspectives on climate change-Marrying the signal from computer models and biological proxies: The Micropaleontological Society Special Publications, The Geological Society, London, p. 459-480.

Dowsett, H.J., Barron, J.A., Poore, R.Z., Thompson, R.S., Cronin, T.M., Ishman, S.E., and Willard, D.A., 1999, Middle Pliocene paleoenvironmental reconstruction-PRISM2: U.S. Geological Survey Open-File Report 99-535, 1 v. (unpaged), maps.

Dowsett, H., Thompson, R., Barron, J., Cronin, T., Fleming, F., Ishman, S., Poore, R., Willard, D., and Holtz, T., Jr., 1994, Joint investigations of the Middle Pliocene climate I-PRISM paleoenvironmental reconstructions: Global and Planetary Change, v. 9, p. 169-195. 
Garzione, C.N., Dettman, D.L., Quade, J., DeCelles, P.G., and Butler, R.F., 2000, High times on the Tibetan PlateauPaleoelevation of the Thakkhola graben, Nepal: Geology, v. 28, p. 339-342.

Garzione, C.N., Molnar, P., Libarkin, J.C., and MacFadden, B.J., 2006, Rapid late Miocene rise of the Bolivian Altiplano-Evidence for removal of mantle lithosphere: Earth and Planetary Science Letters, v. 241, p. 543-556.

Garzione, C.N., Quade, J., DeCelles, P.G., and English, N.B., 2000, Predicting paleoelevation of Tibet and the Himalaya from $¥ 180$ vs. altitude gradients in meteoric water across the Nepal Himalaya: Earth and Planetary Science Letters, v. 183, p. 215-229.

Ghosh, P., Garzione, C.N., and Eiler, J.M., 2006, Rapid uplift of the Altiplano revealed through $13 \mathrm{C}-18 \mathrm{O}$ bonds in paleosol carbonates: Science, v. 311, p. 511-515.

Hill, D.J., Haywood, A.M., Hindmarsh, R.C.A., and Valdes, P.J., 2007, Characterising ice sheets during the PlioceneEvidence from data and models, in Williams, M., Haywood, A.M., Gregory, F.J., and Schmidt, D.N., eds., Deep-time perspectives on climate change-Marrying the signal from computer models and biological proxies: The Micropalaeontological Society Special Publications, The Geological Society, London, p. 517-538.

Markwick, P.J., 2007, The palaeogeographic and palaeoclimatic significance of climate proxies for data-model comparisons, in Williams, M., Haywood, A.M., Gregory, F.J., and Schmidt, D.N., eds., Deep-time perspectives on climate change-Marrying the signal from computer models and biological proxies: The Micropalaeontological Society Special Publications, The Geological Society, London, p. 251-312.

McMillan, M.E., Heller, P.L., and Wing, S.L., 2006, History and causes of post-Laramide relief in the Rocky Mountain orogenic plateau: Geological Society of America Bulletin, v. 118, p. 393-405, doi: 10.1130/B25712.1.
Moucha, R., Forte, A.M., Rowley, D.B., Mitrovica, J.X., Simmons, N.A., and Grand, S.P., 2008, Mantle convection and the recent evolution of the Colorado Plateau and the Rio Grande Rift valley: Geology, v. 36, p. 439-442, doi: 10.1130/G24577A.1.

National Oceanic and Atmospheric Administration, 1988, Data Announcement 88-MGG-02, Digital relief of the surface of the earth: NOAA National Geophysical Data Center, Boulder, Colorado, available online at http://www.ngdc.noaa. gov/mgg/global/relief/ETOPO5/.

Rowley, D.B., and Currie, B.S., 2006, Palaeo-altimetry of the late Eocene to Miocene Lunpola Basin, central Tibet: Nature, v. 439, p. 677-681.

Rowley, D.B., and Garzione, C.N., 2007, Stable isotopebased paleoaltimetry: Annual Review of Earth and Planetary Sciences, v. 35, p. 463-508, doi: 10.1146/annurev. earth.35.031306.140155.

Rowley, D.B., Pierrehumbert, R.T., and Currie, B.S., 2001, A new approach to stable isotope-based paleoaltimetryImplications for paleoaltimetry and paleohypsometry of the High Himalaya since the Late Miocene: Earth and Planetary Science Letters, v. 188, p. 253-268.

Salzmann, U., Haywood, A.M., Lunt, D.J., Valdes, P.J., and Hill, D.J., 2008, A new global biome reconstruction and data-model comparison for the middle Pliocene: Global Ecology and Biogeography, v. 17, p. 432-447.

Spicer, R.A., Harris, N.B.W., Widdowson, M., Herman, A.B., Guo, S.X., Valdes, P.J., Wolfe, J.A., and Kelley, S.P., 2003, Constant elevation of southern Tibet over the past 15 million years: Nature, v. 421, p. 622-624.

Thompson, R.S., and Fleming, R.F., 1996, Middle Pliocene vegetation-Reconstructions, paleoclimatic inferences, and boundary conditions for climatic modeling: Marine Micropaleontology, v. 27, no. 1/4, p. 13-26. 


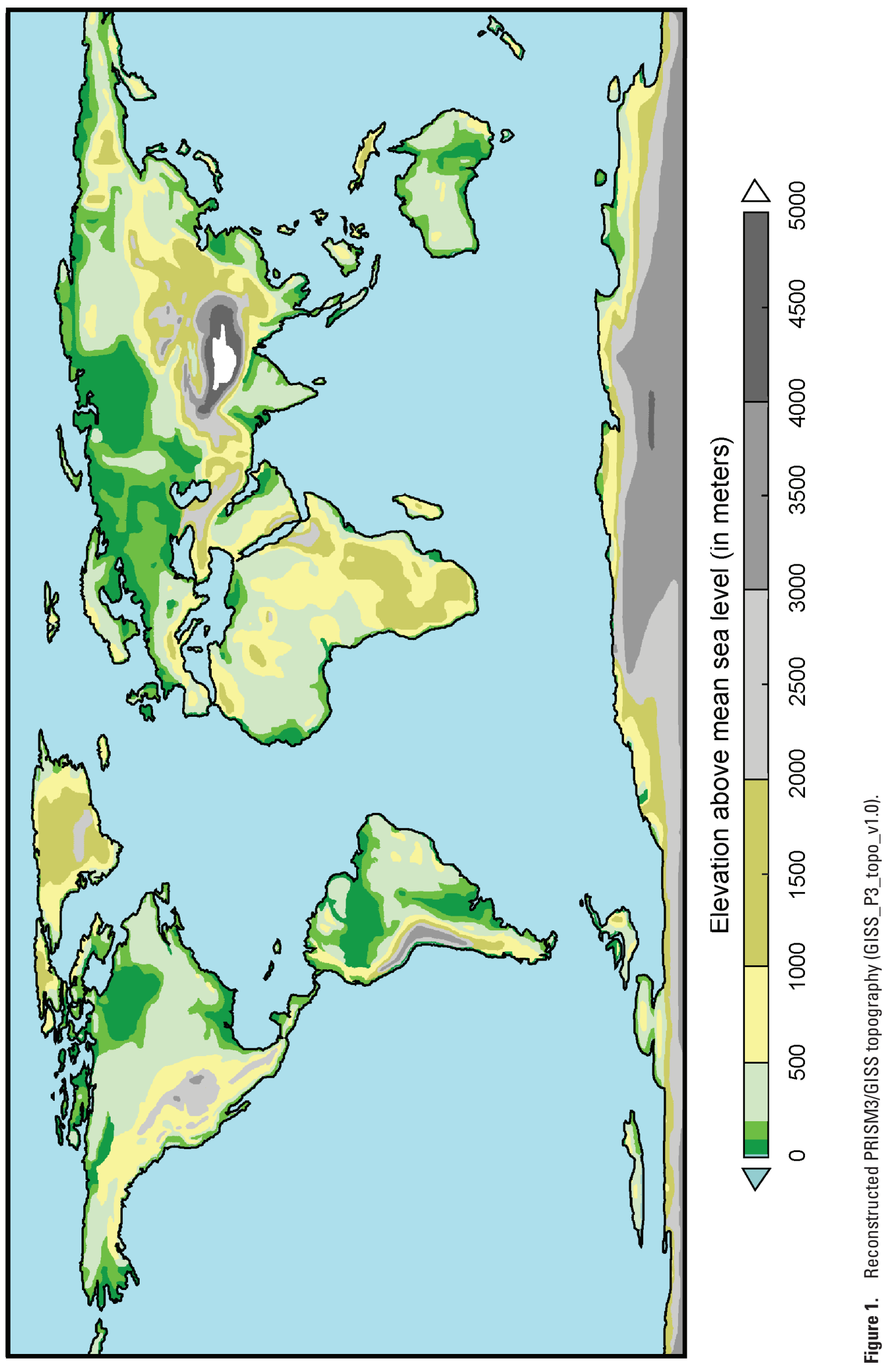




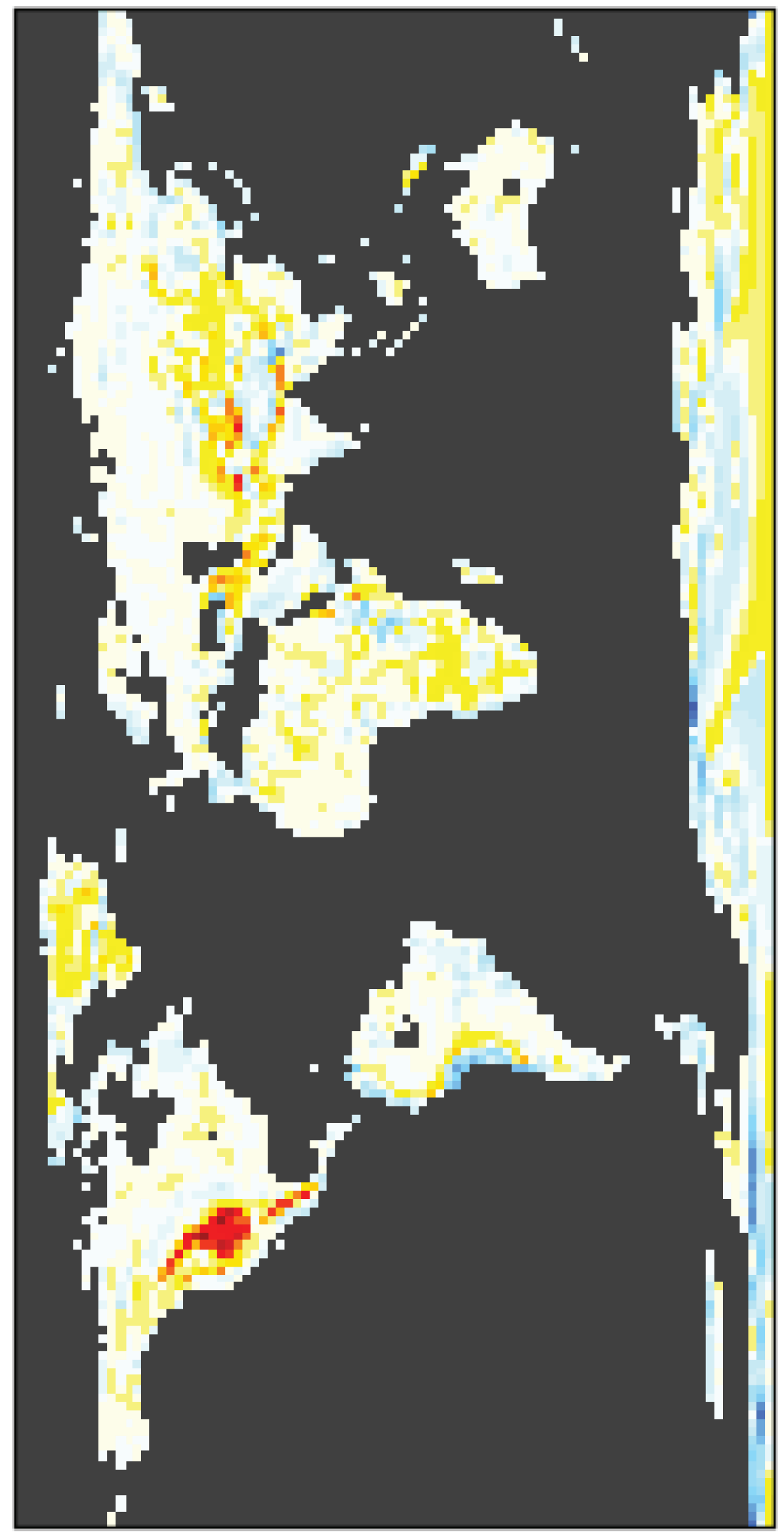

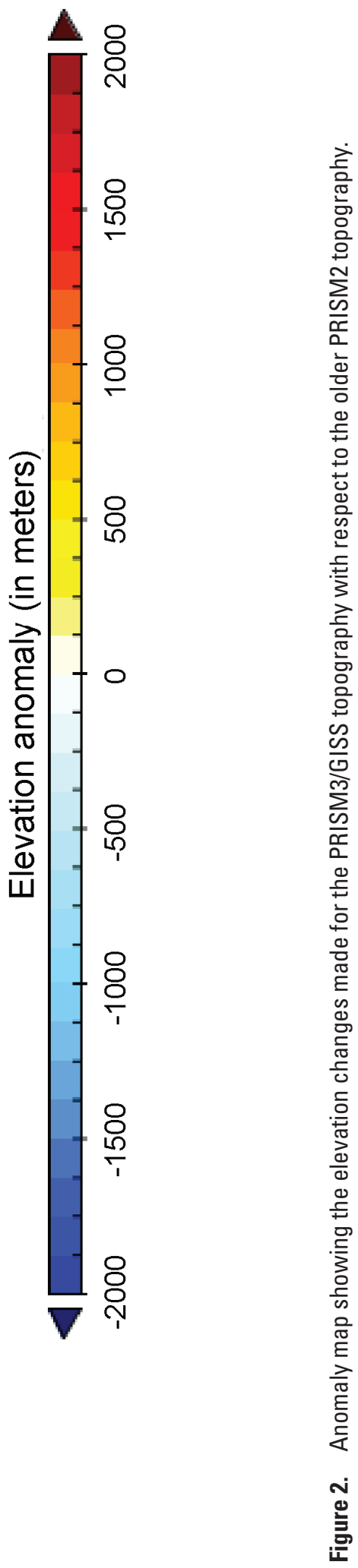

